\title{
7
}

\section{Imagining New Forms of Belonging}

\author{
The Futurity of the Stateless
}

\author{
Eleni Coundouriotis
}

What is the futurity of statelessness? The answer to such a broad question lies partly in the types of stories we tell about the refugee experience and in how we connect past and future. If we claim rights for the stateless, we imagine a future time of statelessness that is something other than the present. To posit new forms of belonging, moreover, presupposes that we have a grasp of the old forms of belonging that failed and caused statelessness. Yet, the process is not simply mechanistic, a toggle from past to future. We cannot settle the past and move on but neither can we imagine futurity without an understanding of the past.

The imagination (through the arts but also through humanistic critical inquiry) provokes us to expand our thinking beyond the familiar. Thus, it can take on the task of interpolating a future for statelessness, of thinking outside the box, to address the rapidly expanding crisis of our epoch. This is a different remit than expecting literature to foster empathic engagement, although the two may not be incompatible. Furthermore, this imaginative discourse contrasts with social scientific descriptive discourses that too frequently diagnose the problem by looking only at what is already in place, suggesting a stalled temporality that reveals a dystopic world of more of the worst aspects of the same. Such descriptive discourses frequently fail to grasp the dynamics of historical change, of relating the past to the future in becoming. The future envisioned here is instead one that finds in statelessness some creative energy for new forms of belonging, even as a resolution to legal statelessness seems elusive. These new forms of belonging will invariably be tested and reconfigured repeatedly, yet they have the potential to move forward the search for a positive path out of the crisis of unbelonging.

Testimony, a complex practice of relating the past to the present, is a privileged discourse in the history of refugees that plays a key role in understanding statelessness as a lived experience. A key contention of this chapter is that testimony, despite what's understood as its retrospective structure, makes legible the futurity of statelessness. Broadly understood as a truthful, first-person account of what happened, 
testimony has a complex relationship with time. Moreover, it has unique narrative features: testimony is performative (a subject gives testimony), eruptive (its key episodes disrupt the exposition of events, coming to the surface of the narrative unexpectedly and with force), and repetitive (we require to hear it multiple times). The experience of statelessness holds on to what anthropologist Michel Agier calls the stages of "destruction" and "exodus." The dislocation of the stateless originated in acute danger, which engulfed the places they called home. ${ }^{2}$ Thus, stuck in limbo in spaces of precarious refuge, they repeatedly give testimony that addresses their past: their history of war, persecution, and forced displacement.

Testimony of these experiences can be hugely consequential in determining the future trajectory and legal status of displaced persons. Furthermore, such occasions for testimony are varied and far from uniform, putting different types of pressure on the accounts we hear. This uneven terrain where particular stories of refugee experience come into focus has the potential to capture aspirations for future belonging born of past trauma. The literary and humanistic endeavor fosters the imagination of what these budding forms of belonging might be. Consequently, this chapter offers reflections on how to create a sense of belonging for the stateless that keeps them in our purview as historical agents who can determine their actions and meaning. Whereas the legal definition of statelessness remains a key category, the chapter examines the experiential implications of statelessness, understanding these as a form of unbelonging. Testimony makes legible the futurity of statelessness and invites creative engagement to elaborate on new aspirations.

Refugee camps, in particular, become places where past and future confront each other. Scenes of testimony - occasions when stories of "exodus" are repeated in refugee camps or other places of refuge - come to characterize something about the new place. ${ }^{3}$ Paradoxically, therefore, new aspirations can emerge from the hindsight of retrospective accounting. Such occasions to remember the story of flight for survival, moreover, recur over long periods, sometimes a lifetime, and might even be repeated by future generations. The persistent iterations of such stories over time accumulate to the point of cohering into a "common story" that binds a refugee community and gives it a "collective voice." 4 A new form of belonging suggests itself in the "collective voice."

What follows is an attempt to explore the possible shape of such new belonging and see how it acquires meaning in an evolving present shaped by memory. Instead of assuming that the past holds secrets we need to uncover but is otherwise finished, reading for the purpose of identifying a new belonging demands a greater effort at integrating the past into the present and future. The past is dynamic and, upon

\footnotetext{
M. Agier, On the Margins of the World (Cambridge: Polity Press, 2008), p. 3.

2 A. Betts and P. Collier, Refuge: Transforming the Broken Refugee System (Milton Keynes: Penguin, 2017), pp. 16-17.

3 Agier, On the Margins, pp. 74-75.

4 Ibid., pp. $75,78$.
} 
repeated reexamination, yields new insight. Statelessness appears at different points in the timeline of testimony, which might extend over generations. The prolonged precarity of the stateless speaks to the urgency with which the new form of belonging surfaces. Statelessness can take on an existential dimension but, as a term, it refers to the legal definition and the loss of rights that go with it. The new forms of belonging redress the existential crisis, creating momentum and pressure to resolve the legal roadblocks to citizenship.

To elucidate this process of an emerging, cohering story that accounts for the past so as to make a claim for future belonging, I examine a historical example, the Armenian Genocide, and the work of Peter Balakian. Balakian not only makes the history of the genocide particularly legible but intuits the futurity of statelessness in his creative work, connecting past and present and offering an expansive view of humanity's becoming that refuses to other the victims of genocide. It is from this ethical claim on his readers that Balakian's work gains wide resonance in the literature on statelessness. I turn first to Balakian's use of history and examine his ambitious layering of time. After a discussion of the temporalities of witness and testimony, I examine how Balakian works with this distinction to make an argument about the futurity of statelessness that draws from the impact of his grandmother's testimony.

\section{HISTORY AND BELONGING}

Our question, therefore, is: What kind of belonging does an extended project of testimony over decades create for stateless persons? Refugees, according to Liisa Malkki, have a "passion for history." ${ }^{5}$ The past matters a lot to them. Can history provide a compensatory space to restitute these subjects sufficiently so they can imagine a future? Agier speaks of a cultural recognition ("based on narration of the experiences of war, exodus, and refuge") that creates a new community to replace what is destroyed while remaining connected to the past. ${ }^{6}$ It is the emphasis on the new that distinguishes this project from other formulations of the politics of memory. Such reconstitution of belonging acknowledges the past but is pragmatically anchored in the present. The "common story" of accumulated testimony actively renegotiates identity in the present and the emphasis on the new is most meaningful for imagining belonging.

There are challenges, however, on this path. The vocabulary of exile and exilic community (which makes reference to territory) has afforded one model of how to

5 Liisa Malkki, "News from Nowhere: Mass Displacement and Globalized 'Problems of Organization" (2002) 3(3) Ethnography 351-360 at 359.

6 Agier, On the Margins, p. 74. 
talk about displaced communities. ${ }^{7}$ Shifting the emphasis away from territory, as I do here following Balakian, leaves one with a difficult history that is unanchored, disjointed from place. Place can only be evoked in the present or the aftermath. In the texture of the present, Balakian thus discovers a traveling memory: a displaced history that speaks in another land. His life-long endeavor to recover the history of the Armenian Genocide in memoir, biography, poetry, and forensic documentation explores the potential for a diachronic belonging - a belonging in time - that speaks to the futurity of the stateless. Balakian's practice is multifaceted and extends the work of testimony: it uses the present to find the past and bring it forward, making it matter in our current lives as we live them. Therefore, the effort reconfigures our belonging in the present through an awareness of the effects of past crimes against humanity. Through ongoing memory work, a new form of belonging is forged that extends our ethical awareness of the stateless in the present.

Moreover, because the Armenian Genocide was perpetrated within the context of a struggle over citizenship rights, it has particular relevance as an example of how to imagine the futurity of statelessness. The pressures of modernization in late Ottoman Turkey reached a climax in the Revolution of 1908, which sought to secularize the state and guarantee equal participation in civil and political life, as well as citizenship, to minority populations. ${ }^{8}$ The revolutionary ideals did not hold, however, and a devastating reaction ensued, resulting in various episodes of mass displacements, mistreatment, and killings that culminated in the genocide a few years later. Importantly, Armenians expressed their allegiance to the revolutionary ideas of 1908 with passion and they understood the huge suffering that followed as the loss, or failure, of citizenship rights. 9

Although the crisis was viewed internationally through the lens of humanitarianism, Balakian accounts for his grandmother's experience through the more robust legal framework of human rights, making her visible as a rights-claiming subject with an outlook to the future. Whereas some displaced Armenians were resettled in the Soviet Republic of Armenia after 1920, most of the displaced survivors came from Anatolia (Turkey) and became long-term refugees, residing in camps and other temporary refuges, until their legal circumstances were clarified. ${ }^{10}$ The expectation of an Armenian homeland to settle the historical wrong was not fulfilled (the Soviet Republic did not become such a symbol). Hence this "common story" that struggled to become legible against denial and silence is also an important example of how history - as an ongoing process of constructing the story of the past - functions as a

7 See, for example, Lucy Stonebridge's discussion of the enduring influence of Edward W. Said's thought on exile in Lucy Stonebridge, Placeless People: Writing, Rights and Refugees (Oxford: Oxford University Press, 2018), pp. 30-32.

8 K. D. Watenpaugh, Bread from Stones: The Middle East and the Making of Modern Humanitarianism (Oakland: University of California Press, 2015), p. 70.

9 Ibid., pp. 71-73.

10 Ibid., p. 168. 
multigenerational point of reference for a community. Balakian's oeuvre as a whole makes legible the complex belonging in a common story that is also specifically addressed to the United States (he speaks very self-consciously as an American) and illuminates the ethical stakes for Americans in belonging together with the stateless.

We can describe Balakian's work as a literature of witness structured in the form of a multigenerational dialogue. He calls his grandmother (who died when he was ten years old) his "beloved witness." ${ }^{11}$ A survivor of the death marches of 1915, when the Ottoman Turkish army forcefully removed the Armenian population of Diarberkir and marched them into Syria, Nafina found temporary refuge in Aleppo. There she earned a living as a seamstress for five years until she entered a home to deliver a wedding dress and saw a carpet that had belonged to her family. She filed a suit, reclaimed the rug, sold it, and paid the passage to America for herself and her two young daughters. ${ }^{12}$ In the United States, she remarried another Armenian refugee, had a daughter (Peter's mother) and lived a second life as part of an affluent, educated, and intellectually inclined family in the New Jersey suburbs of New York City. But her life was carefully circumscribed to remain within a comfort zone that kept the trauma of the past suppressed. She refused to leave the United States even to accompany the family on a trip to Paris. Only in the United States did she feel safe, far enough away from the historical forces that threatened her.

That Nafina might stand as a historical figure who brings the stateless closer to us today is evident from Silvia Salvatici's history of humanitarianism. Salvatici quotes extensively from Nafina's testimony in 1920, recorded in her claim for reparations from the Turkish government. ${ }^{13}$ Salvatici structures her history around key moments of testimony (used as epigraphs throughout the book) by historical figures who are paradigm-setting voices of witness for humanitarianism. Nafina's emblematic status is apparent from her place in this series representing landmark events in the history of humanitarianism that include, in addition to the Armenian Genocide, the Crimean War, Biafra, the Rwanda Genocide, and other events. Nafina's testimony (from her claim for reparations and other documents I discuss below) appears first in Balakian's memoir of his own growing up into consciousness of the genocide, then molds into the common story of surviving the genocide. Salvatici draws together the testimony of an individual survivor with the horrors perpetrated and recasts them in a collective narrative that outlines a historical event on a larger canvas: "The adult men were killed en masse and then the women and children were led to the desert regions of Mesopotamia." ${ }^{14}$

Thus, Balakian can be said to launch his grandmother's significant testimony into the public domain where it becomes a flashpoint for a common story of the

${ }^{11}$ P. Balakian, Black Dog of Fate: A Memoir (New York: Basic Books, 2009), p. 195.

12 Ibid., p. 190.

13 S. Salvatici, A History of Humanitarianism, 1755-1989: In the Name of Others, trans. P. Sanders (Manchester: University of Manchester Press, 2019), pp. 101-102.

${ }^{14}$ Ibid., p. 101. 
genocide. It behooves us, therefore, to pay close attention to his own method of assembling the material for his memoir and for his subsequent writing, where he consistently returns to the genocide and connects it to an ongoing project chronicling the traumatic events of his era (including $9 / 11$ in his collection, Ziggurat). ${ }^{15}$ Balakian's exploration of the history of the genocide contributed to his Pulitzer Prize-winning poetry collection Ozone Journal in which he weaves the work he did in forensic archaeology (uncovering the remains of those who perished in the death marches of 1915) with the memories of his own personal life crisis in 1980s New York: his growing estrangement from his wife and his cousin's suffering in the last stages of AIDS. New York, moreover, is filtered through a more recent past, the 1970s, when he had been happier. Adding yet another layer of time, the entire poem connects to environmental catastrophe and the thinning of the ozone layer, warning of total death from the sun's unfiltered rays: "no plankton, no world: who can take in the dread-." 16 This question ("who can take in the dread-"), which ends with a dash and not a question mark as if it is permanent and unresolved, takes us back to the predicament of those who witnessed mass extermination while anticipating their own deaths. The poet draws an analogy between ecocatastrophe and genocide laying that feeling of "dread" at our door as we confront the fear that we might succumb. And, whereas it is doubtful that we can live up to our moment, we feel the imperative to try and figure out how to do it.

What is most important to our concerns here is the pattern of Balakian's exposition, which overlays the present onto the past in order to demand of the reader an expanded awareness. He places the present danger of violent destruction in the reader's sight. It should not be enough to join the poet in a painful awareness of the enduring trauma of the Armenian Genocide simply as an exercise of humanistic reading. The common story we should reach for grapples with the reality of contemporary mass violence and displacement in continuity with the past, and all of it in the context of environmental catastrophe. The reader might already be primed to recognize ecological catastrophe as a crisis. Balakian then links this by analogy and poetic image to the plight of the stateless, making it hard to refuse the urgent predicament of the stateless in our contemporary moment. Moreover, we realize that if we do not broaden to an understanding of statelessness and precarity in the present, we risk the kind of complicity in silence similar to the one that impeded Balakian's effort to apprehend the full import of his family's history. As we learn from the text, the family's silence about the genocide kept the young Peter in ignorance until his college years. Reading the memoir, we come to an appreciation of Balakian's discovery of history and, as a result, cannot blind ourselves to a similar interconnectedness with world events in the present.

15 P. Balakian, Ziggurat (Chicago: University of Chicago Press, 2010).

16 P. Balakian, "Ozone Journal, \#17," in Ozone Journal (Chicago: University of Chicago Press, 2015), p. $3^{8}$. 
Balakian brings to mind Dori Laub's highest sense of witness: the expectation that to witness is to have interruptive force and intercede with the truth to stop a particular action. Laub describes this interruptive witness as a "concurrent" witness that calls out the truth of an event as it is unfolding. ${ }^{17}$ The injunction to interrupt is suggestive for the kind of witnessing that Balakian seeks and his belief that one must constantly renew the witnessing of past atrocity in order to forestall its repression in memory. His grandmother is his "beloved witness" in the sense that Peter, as her beloved claimed as an intimate extension of herself, must carry on her witness. The historical figure (his grandmother) leaves behind testimony that he uses as material to posit his writing as "concurrent witness" to his own time. Such witness accounts create an enormous and hard-to-fulfill expectation of authenticity. How do they manage these expectations? Within literary discourse, we find a partial answer in the figure of the poet, as Balakian understands well.

The special function of the poet to bestow authenticity to historical experience is well established. Turning to the opening of Anna Akhmatova's "Requiem,"18 legal scholar and human rights practitioner Ron Dudai reminds us that the poet is asked to "describe this": the scene of women standing outside Leningrad prison as they wait for word about their imprisoned men. ${ }^{19}$ Akhmatova's celebrated poem gives witness to the sufferings caused by Stalin's purges in the 1930s. For Dudai, it is significant that the poet is asked to "describe this" as opposed to being asked "to help." Description is intervention. To give voice to a collective experience demands a special skill but also a person with recognized authority to speak for the group and persuade the targeted audience of the authenticity of the experiences. These are the poet's burdens, and they clarify for us what Balakian tasks himself with. As Dudai explains, however, we have come to expect from human rights reports of abuses that description gains authority by being pared down, "allowing the facts to speak for themselves," and suppressing literary elements or overly narrative qualities. ${ }^{20}$ In practice, we construct evidence rhetorically - evidence is not what is true but that which is used to persuade us of the truth. ${ }^{21}$ Literature, therefore, can persuade by providing the context for recognition, and hence also for potentially new forms of belonging.

17 S. Felman and D. Laub, Testimony: Crises of Witnessing in Literature, Psychoanalysis, and History (New York: Routledge, 1992), p. 84.

18 A. Akhmatova, "Requiem," in S. Kunitz and M. Hayward (eds. and trans.), Poems of Akhmatova (Boston, MA: Little, Brown and Company, 1973), pp. 99-117.

19 R. Dudai, “'Can You Describe This?' Human Rights Reports and What They Tell Us about the Human Rights Movement” in R. A. Wilson and R. D. Brown (eds.), Humanitarianism and Suffering: The Mobilization of Empathy (Cambridge: Cambridge University Press, 2008), pp. $245-246$.

20 Ibid., p. 249.

${ }^{21}$ T. Keenan, "Getting the Dead to Tell Me What Happened: Justice, Prosopopoeia, and Forensic Afterlives" in Forensic Architecture (ed.), Forensis: The Architecture of Public Truth (Berlin, Germany: Sternberg Press and Forensic Architecture, 2014), pp. 43-44. 
Theories of testimony have explored the difficulties of bringing forth the outline of events suppressed by trauma. As Shoshana Felman puts it, traumatic events are "events in excess of our frames of reference" that are difficult to talk about. ${ }^{22}$ The traumatic event is the lacuna around which an account of trauma's toll blossoms. Expanding on this idea, Laub calls our attention to the "historical gap" that separates the events recounted from the recounting, and the difficulty or near impossibility of transmitting testimony in real time. ${ }^{23}$ As noted, he provocatively suggests that should "concurrent witnessing" be achieved, it would bring about an interruption of the event being witnessed. Although Laub presents this as unlikely, its possibility is the great hope for what a mission to give witness might accomplish for human rights: to intervene and interrupt the harm. Witnesses in real time can thus be agentic subjects at the scene of catastrophe. NGOs such as Doctors Without Borders have, in fact, made witnessing a foundational aspect of their practice. ${ }^{24}$ By contrast to witnessing, testimony is the task of retrieving the contours of the event retrospectively through the obfuscations of trauma. This is a process that takes time.

In a sense, Balakian fuses the two temporalities that distinguish witness from testimony: he acts as a witness in the present by responding to his discovery of a historical testimony that has taken a considerable amount of time to surface. His involvement in forensic projects to find the remains of Armenian victims carries forward the relevance of his findings to his contemporary moment, as is evident in the poems of Ozone Journal that weave this search for remains into an account of the challenges of our time. Forensics shares some qualities of the interruptive witness. Balakian's poetic practice and its corollary in forensics suggest that the "common story" of the Armenian diaspora, to whose formation Balakian has contributed significantly, imagines a broader belonging in solidarity with the stateless today. This is more than what Agier calls the "existential community" shaped immediately after a catastrophe. ${ }^{25}$ The pull of this new belonging pushes us all to act as interruptive witnesses to create a new futurity for the stateless. Whereas ultimately the goal is to resolve legally the condition of statelessness, the futurity alluded to here creates momentum toward recognition and, from there, legal and political change.

\section{THE CLAIMS ON THE “BELOVED WITNESS”}

In Black Dog of Fate, Balakian reverse-engineers the authenticity of his grandmother's testimony: the historical truth he discovers as an adult grows out of his affective attachment, which lends authenticity to Nafina's testimony. Moreover, his method of exposition demonstrates how the present opens up the past and is of the

${ }^{22}$ Felman and Laub, Testimony, p. 5.

23 Ibid., p. 84.

24 P. Redfield, Life in Crisis: The Ethical Journey of Doctors without Borders (Berkeley: University of California Press, 2013), p. 100.

25 Agier, On the Margins, p. 74. 
most consequence in shaping a future. Balakian's "epiphany," recounted as the discovery and retransmission of his grandmother's words, underscores the impact of Nafina's testimony. ${ }^{26}$ Importantly, an even more traumatic testimony by his Aunt Dovey surfaces alongside Nafina's witness. Gaining confidence from Peter's recognition of Nafina's empowered stance (apparent in her claims for reparations), his aunt comes forth with her memories. This synergy between the two historical voices demonstrates how a context of multiple testimonies emerges over an extended timeline. Decades separate these two testimonial utterances. Dovey gives Balakian a first-person account of the signature atrocities of the Armenian genocide, including the death of men by crucifixion and mutilation and the burning alive of women, who were first forced to dance while being whipped and beaten in public. ${ }^{27}$ This difficult narrative is presented to the reader only after Balakian's extensive and poignant account of his childhood bond with his grandmother when the genocide was never discussed and he had no understanding of it. His retrospective account of his own growing up is filled with a sense of belated recognition of the signs genocide left on his family. These flashes of recognition, anchored in quotidian details, lend authenticity to his grandmother's testimonial legacy and free his aunt to speak to him. As he notes in a poem: "memory was focus, detail, the thing -" observed in the ordinary world that surrounds us. ${ }^{28}$

In large part, what Balakian describes in his memoir are the effects of postmemory: the inherited trauma that survivors' families experience, resulting from the silences and the unspoken, unmourned past. The passage of time, deracination, and the loss of home together condition post-memory. ${ }^{29}$ Balakian channeled this haunting into his poetry. What he didn't know he knew burst forth in an early poem, "The History of Armenia," composed when he guiltily skipped his grandmother's memorial service ten years after her death to spend the weekend with his girlfriend. The process of writing the poem exposed how relevant the affective history of the genocide had been to him. Writing "The History of Armenia" reconnected him to his grandmother: "I could bring the two of us together again and create what she had in her encoded way told me. I realized that she was my beloved witness, and I the receiver of her story." ${ }^{\circ}$ Here he is both interpreting his grandmother's code to understand her and creating new meaning by recasting their relationship in the present.

Thus, Black Dog of Fate can be read as a tribute to Balakian's grandmother, but it is also most importantly a story of Balakian's discovery of the history of the genocide,

${ }^{26}$ R. P. Mosby, "The Voice of History: An Interview with Peter Balakian” (2001) 67(3) New Letters at 49 .

27 Balakian, Black Dog, pp. 222-225.

${ }_{28}$ P. Balakian, "Ozone Journal, \#9," in Ozone Journal, p. 33.

29 M. Hirsch, Family Frames: Photography, Narrative and Postmemory (Cambridge, MA: Harvard University Press, 1997), pp. 22-23.

30 Balakian, Black Dog, p. 195. 
and his push against denial and silence. It exemplifies how coming to grips with the past is an ongoing, difficult process that simultaneously mediates the relationship with the present. As Balakian's lived experience, the confrontation with the past is necessarily also part of the forward-moving temporality of his life into which he carries an expansive sense of the predicament of statelessness.

Moreover, the text obsessively records the importance of a sense of place in belonging. Regions, neighborhoods, streets, bus routes, construction sites, home interiors are all meticulously described. If these details evoke in Balakian's readers a rich recognition of a particular place and time in metropolitan New York, they then also suggest that the place left behind by his family by analogy must have had an enormous affective significance. Its memory is teased out in the food, language, folk stories, and religious ritual that surrounded the young Peter. Growing up, he navigated these with some selectivity: loving the food, being perplexed by much of the rest, and in a flashpoint of conflict with his father not recognizing what he had no way of knowing, "what the Turks did to us." ${ }^{11}$

Reading becomes instrumental in bringing the contours of the past into the present. During a summer job while he was in college, Balakian spends his free time reading Ambassador Morgenthau's Story, ${ }^{32}$ which he pulled from his parents' bookshelf because he had been intrigued by its possibility and was now ready to read it. ${ }^{33}$ Yielding to Morgenthau's witness from the times and quoting extensively from his book, Balakian takes his reader along in his discovery of the magnitude of the atrocities. This story of reading, in which we participate as Balakian's surrogates, mimics a structure of human rights storytelling that is, in fact, widespread. Adam Hochschild, for example, structured King Leopold's Ghost, his human rights history of the atrocities in the Belgian Congo, around similar scenes. Hochschild tells us, therefore, how Edmund Morel discovered the human rights abuses in the Congo by reading ships' manifests and puzzling over what information was missing. ${ }^{34}$ The idea that reading leads to discovery of fact is a bit peculiar in these cases: the facts are rarely new, and thus can't be discovered in a strict sense. Even to say that this amounts to a personal discovery isn't quite accurate because by the time Balakian, for example, reads Morgenthau he already has by his own admission a basic frame for these events from fragmented information that has been passed down to him. So, what is the significance of this story of reading? How does it offer something new?

The power of reading is frequently discussed in terms of its affective influence. It cultivates human sympathy and sharpens our abilities as ethical thinkers. Both dimensions are at play here but we need to put our finger on something in addition:

$3^{1}$ Ibid., p. 100.

${ }^{2}$ H. Morgenthau, Ambassador Morgenthau's Story (New York: Doubleday, Page and Company, 1918).

33 Ibid., p. 153.

34 A. Hochschild, King Leopold's Ghost: A Story of Greed, Terror and Heroism in Colonial Africa (New York: Mariner, 1999), pp. 178-189. 
in this example, the activity of reading becomes the plot of a story that explains retrospectively the impact of a text. This is different from drawing attention to a reader's interpretation of the text. The story of reading dramatizes for us the experiential impact of reading, its transformative power, which, moreover, dramatizes the acquisition of a new understanding - deeper, more complex, more immediate - of past events. Stories of reading in a human rights context are about connecting with history in a way that rewrites its narrative.

The common story forged through the accumulated testimony of events of mass displacement can appear in creative work such as Balakian's where it ignites a larger public awareness of an important past history and makes us aware of our connection to mass violence in our own time. This discovery in a shared story of reading situates the text as a reference point for belonging. The question of temporality with which this chapter began is pivotal. New forms of belonging can potentially be capacious but they require a flexible temporality, one that accommodates the flashes of traumatic memory and the "dread" of impending catastrophe in the present.

Balakian first published his memoir in 1997, a year before Hochschild's history appeared and around the same time that there was a burst of literary works defining themselves in terms of human rights. ${ }^{35}$ Generally speaking, the late 1990 was a period of intensified engagement of literature with human rights and we find this reflected in Balakian's text where on several occasions he is explicit about his framing. Describing his reaction to hearing the phrase "remember the starving Armenians" as a college student and realizing that it existed in the popular conscience but he had never heard it at home, Balakian remarks: "No one ever told me that the image of Armenians starving to death was, for Americans, a slogan for the most dramatic human rights issue of the day." ${ }^{36}$ The starving Armenians are referred to in the historiography as subjects of humanitarian concern, ${ }^{37}$ but Balakian suggests that humanitarian concern elided the main issue. Morgenthau's account instead gets it right. He describes a genocide before the paradigm-setting history of the Holocaust and the body of international human rights law that followed and made such a designation recognizable. $3^{8}$

Balakian's story of reading culminates in his recognition of his grandmother as a human rights claimant. He reproduces the legal documents that record his grandmother's claims for reparations from the Turkish government in 1920. This is not only a claim for reparation of property but a claim made on the basis of the violation of her physical integrity rights and the suffering caused. The document ends with this statement: "The Turkish government is responsible for the losses and injuries happened to [me], because I am a human being and a citizen of U.S.A., I am under

\footnotetext{
35 James Dawes, The Novel of Human Rights (Cambridge, MA: Harvard University Press, 2018), p. 29.

36 Balakian, Black Dog, p. 173.

37 Watenpaugh, Bread from Stones, p. 33.

$3^{8}$ Balakian, Black Dog, p. 138.
} 
the support of human and international law."39 Nafina intuits the language of human rights and claims a future. These documents reveal facts that Balakian was unaware of: that Nafina was an American citizen by marriage to an Armenian merchant who was a naturalized American (and not Balakian's grandfather) and who had returned to Diarbekir in 1915 and died during "our deportation." Poignantly, she states: "my husband Hagop Chilinguirian being dead on the way." $4 \circ$ The documents also include the list of other relatives that perished and thus outline her and her brother's claim to the family property.

Most striking, however, is his grandmother's stance as a human rights claimant on the basis of her United States citizenship by marriage: because I am "a citizen of U.S.A," she says signing from Aleppo, Syria, she has the "support of human and international law." Unusual as her circumstance was, it shows that without the good fortune of an American citizenship by marriage, she would have no grounds from which to make a legal claim. She is acutely aware of this privilege, announcing this citizenship as the basis of her claim, but also appears anxious that it will not be recognized. Nafina's answer to "Question 63" of the legal form (asking her to explain the circumstances of her loss of property) states that her husband's naturalization papers and passport were taken from him, and therefore she is not in possession of them. Teetering between statelessness and US citizenship as a refugee in Aleppo, Nafina persists in her claim. Thus, here too her thinking is proleptic. She intuits the logic of Hannah Arendt's famous "right to have rights:" without citizenship, one cannot claim rights, thus human rights are not universal but conditioned on a particular form of belonging, that of citizenship. ${ }^{41}$

Included in Nafina's legal testimony are also the devastating details that outline the truth of the death march. Such details situate Nafina in the particulars of an established history but reveal to Balakian a new person, his grandmother in a different life, on a death march, widowed and accompanied by two young daughters. She withholds the details of her husband's passing, saying only that the male deportees were killed "one by one" and that her husband "feeble and indisposed, being subjected to such conditions, and seeing our relatives killed unhumanely [sic], he could not support the life, and died." ${ }^{2}$ Balakian quotes extensively from the document and intersperses these passages with fragments from the most intense memories he had of his grandmother, scenes he has already rendered for the reader in the book's eloquent, intensely affective opening chapters.

Reconciling the grandmother who doted on him and told him fantastic stories (including the one about Fate and the dead black dog) to the historical figure, Balakian bridges the two selves she had not been able to integrate in her own life.

39 Ibid., p. 211.

$4^{\circ}$ Ibid., pp. 202, 204.

$4^{11}$ H. Arendt, The Origins of Totalitarianism (New York: Harvest Books, 1976), p. 296.

$4^{2}$ Ibid., p. 210. 
This harmonizing is at once a fiction and a history that occupies an expanded space created by the multilayered acts of retrospection. For the reader, it is less a matter of sympathy as it is of a deeper understanding of what we know. Such recognition can afford a sense of belonging, a response against the forces of silence.

The memoir exceeds Balakian's personal remembrance of growing up and becoming a poet in suburban New Jersey. This surfeit significance gains over time and literally expands the text itself. The tenth anniversary edition adds two new chapters that give an account of Balakian's travels to Turkey and Syria where he explores his grandmother's path from Diarbekir, to the death camps of Der Zor, and then to Aleppo. The added material shifts our impressions of his grandmother once more by recasting her as the figure of the person in flight, a figure that is an enduring preoccupation of human rights. The deployment of its symbolism for the stateless by Balakian, therefore, updates the human rights framing for his text from 1997 to 2007 . At the same time, these two added chapters perhaps make Nafina more spectral. She is less present than she was in the memoir as originally published. The narrative of flight distances the reader as it is a well-worn convention. But Balakian's lens also widens and, taking in the places he visits, he addresses the magnitude of the historical event. Reexamining the past is always an incomplete task to be renewed over and over.

What literature and the arts offer to an exploration of statelessness goes beyond the documentary or the illustrative. Such works help us imagine the new by engaging history and its deep marks on our present condition. They afford a type of recognition cast as discovery that urges us to witness and hence interrupt the ways the past continues into the present. Through this witness, the stateless find new interlocutors with whom to claim belonging. The broadened sense of participation in history that Balakian instils in his readers links explicitly to an ethos of human rights: Everything is pegged on the idea that human rights give legibility to the type of responsible subjectivity that extends belonging to the stateless. Once again, this is in reference to a kind of "existential" belonging, as Agier puts it, in advance of a legal resolution, but it keeps such a resolution in mind. If reading affords a sense of place while maintaining the discomforting irresolution that accompanies the condition of statelessness, it may turn us outward to coalition building rather than inward to a sense of individual moral uplift. For the displaced, moreover, keeping alive an evolving sense of belonging - crucial for owning one's historical subjectivity - requires receptive interlocutors willing to engage one's story. 